\title{
Where Is Syntax? \\ Syntactic Aspects of Left Dislocation in Dutch and English.
}

by Jan-Wouter Zwart, University of Groningen

\section{Introduction}

Movement of syntactic objects, yielding variation in word order across constructions and languages, is characterized by Chomsky (1995:222) as "an irreducible fact about human language, expressed somehow in every contemporary theory of language, however the facts about displacement may be formulated." The displacement property of language entails that syntactic elements may belong in various positions in the syntactic structure at the same time. A syntactic object has various properties (features) that need to be satisfied (checked) in various positions in the structure. The theory of grammar specifies what these properties are, and where and how they are satisfied.

Chomsky (1995) calls that part of the grammar (viewed as a "mental organ") that executes the displacement of syntactic objects the "computational system of the human language" or " $\mathrm{C}_{\mathrm{HL}}$ ". Core cases of displacement that are handled by $\mathrm{C}_{\mathrm{HL}}$ involve A-movement of noun phrases, as in passive and raising constructions:

$$
\begin{aligned}
& \text { a. } \quad \mathrm{John}_{\mathrm{i}} \text { was arrested } \mathrm{t}_{\mathrm{i}} \\
& \text { b. } \mathrm{John}_{\mathrm{i}} \text { seems }\left[\begin{array}{ll}
\mathrm{t}_{\mathrm{i}} & \text { sick }
\end{array}\right]
\end{aligned}
$$

In the sentences in (1), John belongs in two positions. In one of those positions, indicated by a trace $(t)$, John is assigned a thematic role (theta-role) from its sister (the verb arrest in (1a), the adjectival predicate sick in (1b)). On the basis of this, John will be interpretable as the internal argument of arrest in (1a), and as the external argument of sick in (1b). The underlying assumption here is that thematic roles are assigned in a strictly local configuration, ideally as a function of a sisterhood relation (Chomsky 1986). The displacement property of human language is illustrated in (1) by the fact that John does not appear in the position in which it is assigned a thematic role. Apparently, John also belongs in a second position, the structural subject position of the clause. The theory should therefore specify a property of John that is satisfied in the subject position. Various proposals to this effect have been made (involving licensing of phifeatures expressing person and number of the subject, checking of the Case features of John, and satisfying a particular property of the clause, namely that every clause must have a subject - the Extension of the Projection Principle or EPP of Chomsky 1981). For our purposes, let us simply state that John has particular features relating to its "syntactic function", and that these features are checked off in a particular syntactic position. It is assumed, again, that the relation involved in the feature checking is strictly local, leading to the influential hypothesis that the licensing is executed by an adjacent "functional head" $\left(I^{\circ}\right)$ :

$$
\left.\begin{array}{lllll}
\text { a. } & J_{o h n_{\mathrm{i}}} & \mathrm{I}^{\circ} & {\left[\text { was } \left[\text { arrested } \mathrm{t}_{\mathrm{i}}\right.\right.}
\end{array}\right]
$$

Crucially, the syntactic position in which the syntactic function of John is checked is a different position from the syntactic position in which John is assigned a thematic role. In order to satisfy all the properties of John, displacement is necessary -- still assuming a strictly local relation of theta-role assignment and feature checking.

Chomsky (1995) describes the displacement property of language in terms of movement. $J o h n$ in (1) is generated in one position, and moved to another position. On this view, $\mathrm{C}_{\mathrm{HL}}$, comprises two operations: Merge (which combines two elements, for example John and arrested in (1a), yielding a structure like (3)) and Move (which detaches John from its base position and merges it with the root of the structure, as in (4)).

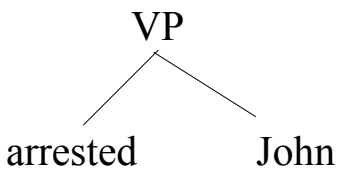


(4)

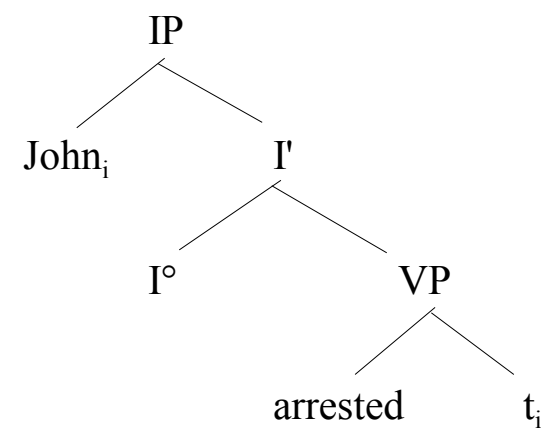

Other ways of describing the displacement property, not involving a derivation with temporally ordered steps, are also possible. For instance, one might simply state that syntactic objects belong in various positions (again based on the assumptions regarding local grammatical relations of thematic role assignment and feature checking), and that empty elements may be generated in those positions that are not actually occupied by the relevant syntactic object (cf. Koster 1987). However, since this is a matter of execution, we will adhere to the more familiar derivational frame of description (see Epstein 1995 for potential advantages of a derivational approach over a nonderivational ("representational") approach). The main point remains to describe as accurately as possible the formal features and licensing relations involved.

Describing the relevant features and relations is often referred to as the problem of the "triggers for movement". Ideally, a trigger "forces" movement, excluding the possibility of optional movement. The description of passive and raising above is successful in this respect. If John is not moved to the structural subject position, the construction yields an ungrammatical sentence (in terms of Chomsky 1995, "the derivation does not converge", as the features relating to the syntactic function of John have not been checked):
a. $\quad *$ Was arrested John
b. $\quad *($ It) seems John sick

Typically, then, a movement $\mathrm{M}$ in a construction $\mathrm{C}$ in a language $\mathrm{L}$ involves the absence of word order variation regarding $\mathrm{M}$ in $\mathrm{C}$ in $\mathrm{L}$. The fact that movement has occurred can only be concluded from general considerations regarding feature checking and theta-role assignment configurations (in particular, the local character of the grammatical relations involved). Nevertheless, it seems that optional movement is not altogether absent from human language.

One way to account for optional movement while leaving the minimalist assumptions regarding movement and feature checking unscathed, is to assume that optional movements fall outside of the domain of $\mathrm{C}_{\mathrm{HL}}$. They may be triggered by other factors, not contributing to the general concerns of licensing and feature checking, but touching on more pragmatic issues, involving theme-rheme structures, topic-focus configurations, and the like. The recent "minimalist" literature has not much to say about these subjects, and Chomsky (1995:324-325) appears to assume that they are not part of syntax proper, but of a domain of grammar that is uniquely concerned with "surface phenomena", not contributing to the interface of the grammar with the Conceptual-Intentional component of the mind/brain (referred to as $L F$ ), generated by $\mathrm{C}_{\mathrm{HL}}$.

I agree with Michael Rochemont (this volume), however, that such a partitioning of word order phenomena in " $\mathrm{C}_{\mathrm{HL}}$ syntax" and "non- $\mathrm{C}_{\mathrm{HL}}$ syntax" would be premature. It presumes that the features relevant for movement in the $\mathrm{C}_{\mathrm{HL}}$ syntax are sufficiently well-known and understood. It also seems to assume that discourse factors cannot condition the presence of features. In other words, the features triggering movement must be autonomous. However, this assumption is clearly wrong for many constructions that have been successfully described in terms of movement triggered by feature checking requirements: interrogatives, imperatives, conditionals, subjunctives, etc.

What these constructions have in common is that some outside requirement forces the presence of a particular formal feature in the clause. For instance, a yes/no-question requires a particular yes/no-interrogative feature (and often, a particle) in the clause initial position (say, in a functional head). There is no general, autonomous requirement for this functional head to have 
the interrogative feature manifested by the particle. The interrogative feature apparently is a variable property of the relevant functional head (alternatively, the presence of the functional head is a variable property of the clause). However, without it, the clause would not yield a felicitous utterance in the discourse.

It seems that many constructions that might be taken to involve optional movement have this nonautonomous, "variable" quality. The crucial question is whether we can distinguish the features that are relevant for the movement involved, and whether this feature can be linked to the requirements set by the discourse in any way.

In this article, I will discuss one typical discourse related syntactic process, fronting, in Dutch and English (cf. Prince, this volume). I will argue that fronting is applied in the same discourse situations in both languages. However, there is a syntactic difference between fronting in the two languages: in Dutch, but not in English, fronting can always be accompanied by an auxiliary process of $d$-word fronting. I will argue that $\mathrm{d}$-word fronting is an autonomous, parametrized syntactic process best described in terms of feature checking. The presence of the feature that is checked by d-word fronting is conditioned by the discourse situation.

The analysis suggests that the "fronted" phrase itself is not dislocated, but base-generated at the left edge of the sentence (as argued by Weerman 1989, Zwart 1993). The d-word is a (possibly empty) pro-form of the "fronted" phrase, which is moved to the left in order to check a discourse related feature in the head of the clause.

\section{Fronting in Dutch}

Neutral word order main clauses in Dutch show the pattern in (6):

$$
\text { subject - finite verb - (XP) - object - (XP) - verbal elements }
$$

In (6), the subject and the finite verb are adjacent, adjuncts appear in the positions marked by $X P$, and the "verbal elements" include (Small Clause) predicates, verb particles, and nonfinite verb forms.

Fronting, as it is understood here, shows the pattern in (7): ${ }^{1}$

$$
\text { YP - finite verb - subject - (XP) - object - (XP) - verbal elements }
$$

In (7), a phrase $Y P$ appears at the left edge of the sentence, immediately followed by the verb and the subject. (For many speakers, the finite verb and the subject do not necessarily have to be adjacent in (7), but we will ignore that issue here.) $Y P$ in (7) may in principle be any of the elements to the right of the finite verb in (6), though not all frontings would be equally felicitous.

The fronting in (7) is often referred to as "topicalization" in the literature on Dutch. However, this term is inaccurate, as it is not clear that YP in (7) is necessarily the topic (see Prince, this volume, for discussion).

(6) and (7) are illustrated in (8) and (9):

$$
\begin{array}{lllll}
\text { Jan heeft gisteren } & \text { het boek } & \text { snel terug gebracht } \\
\text { John has yesterday the book } & \text { fast } & \text { back brought } \\
\text { subj. Vf XP } & \text { obj. } & \text { XP } & \text { verbal-elements } \\
\text { "John returned the book quickly yesterday." } &
\end{array}
$$
a. Gisteren
heeft Jan het boek snel terug gebracht
b. $\quad$ Dat boek
has John the book quickly back brought
b. that book
heeft Jan gisteren snel terug gebracht
c. Snel
has John yesterday quickly back brought
quickly
heeft Jan gisteren het boek terug gebracht
has John yesterday the book back brought

\subsection{Properties}


The properties of fronting in Dutch are listed in the following subsections.

\subsubsection{Inversion}

Fronting in Dutch necessarily involves subject-verb inversion. See (9) and (10):

(10) a. *Gisteren Jan heeft het boek snel terug gebracht yesterday John has the book quickly back brought

b. $\quad *$ Dat boek Jan heeft gisteren snel terug gebracht that book John has yesterday quickly back brought

c. *Snel Jan heeft gisteren dat boek terug gebracht quickly John has yesterday the book back brought

Inversion in Dutch also occurs in other types of main clauses: wh-questions (11a), yes/noquestions (11b), imperatives/adhortatives (11c), and counterfactuals (11d):

(11) a. Wat heeft Jan terug gebracht?
what has John back brought
"What did John return quickly?"
b. Heeft Jan het boek terug gebracht?
has John the book back brought
"Did John return the book?"
Brengen jullie dat boek eens terug!
bring "Return that book, you!" book once back
d. Had Jan dat boek maar terug gebracht
had John that book but back brought
"If only John had returned that book."

\subsubsection{Root clauses only}

Fronting in Dutch takes place in root clauses only:

$$
\begin{aligned}
& \text { Ik zei dat } \\
& \text { I said that }
\end{aligned}
$$
a. (?)..gisteren Jan het boek snel terug gebracht had
yesterday John the book quickly back brought had
b. $\quad *$..dat boek Jan gisteren snel terug gebracht had that book John yesterday quickly back brought had
c. ..snel Jan gisteren dat boek terug gebracht had
quickly John yesterday the book back brought had

In embedded clauses, the finite verb is part of the group of "verbal elements" indicated in (1).

(12a) is not necessarily ungrammatical, because many speakers of Dutch allow adverbs to appear between the complementizer and the subject (the situation is the same as with the finite verb and the subject in (2)). There is no evidence that (12a), if judged grammatical, involves fronting.

(12b) and (12c) are only acceptable with a special intonational pattern, in which both the fronted element and some other element to its right receive a marked high pitch:

(?)..dat SNEL Jan gisteren dat BOEK terug gebracht had that quickly John yesterday that book back brought had

Two observations suggest that sentences like (13) involve a different phenomenon from the fronting phenomenon under consideration here. First, the fronting phenomenon under 
consideration here does not involve the marked intonational pattern in (13). Second, the intonational pattern in (13) does not necessarily involve fronting to the left edge of the clause:

..dat Jan SNEL gisteren dat BOEK terug gebracht had

that John quickly yesterday that book back brought had

In (14), the VP-adverb does not appear in its canonical position to the right of the sentence adverb. Therefore, it presumably has been shifted to the left, by a process identified by Neeleman (1994) as "focus scrambling". (13), then, appears to be a subcase of focus scrambling as well.

In conclusion, the fronted phrase in fronting constructions in Dutch must be at the left edge of the sentence, not of the clause.

Two apparent counterexamples from colloquial Dutch confirm this conclusion. In colloquial Dutch, embedded verb second constructions occur in circumscribed contexts (Zwart 1993:287). The contexts are the same as the ones identified by Hooper and Thompson (1973) as allowing embedded root phenomena in English. A core case involves a verbum dicendi in the main clause:
a. Jan zei dat hij had gisteren het boek snel terug gebracht John said that he had yesterday the book quickly returned
b. Jan zei dat dat boek had hij gisteren snel terug gebracht John said that that book had he yesterday quickly returned

As (15b) shows, embedded verb second clauses do show fronting. However, as Hooper and Thompson (1973) argue, embedded clauses showing root phenomena are not, strictly speaking, embedded. The main clause has a parenthetical function, and the "embedded clause" is for all intents and purposes an independent sentence. As discussed in Zwart (1993), many phenomena indicate that the "embedded clause" in (15) is independent from the "main clause": there is no subject cliticization to the complementizer, the "embedded clause" is an island for extraction, and the complementizer does not block movement of the finite verb, like it does in ordinary embedded clauses.

We may therefore conclude that embedded verb second clauses are independent sentences. Hence, the fact that embedded verb second clauses show fronting confirms the generalization that fronting involves the root node of independent sentences only.

A second phenomenon of Colloquial Dutch that appears to contradict the generalization that fronting is a root phenomenon is the apokoinou phenomenon (discussed by De Vries (19101911) and Jansen (1981)). In constructions showing apokoinou, the sentence makes a restart:

$$
\begin{array}{lll}
\text { Jan heeft } & \text { gisteren } & \text { heeft-ie dat boek terug gebracht } \\
\text { John has } & \text { yesterday } & \text { has-he that book back brought }
\end{array}
$$

The sentence in (16) starts off according to the pattern in (1), but the adverb gisteren "yesterday" starts off a new sentence, according to the pattern in (2). Again, this new sentence is not obviously "embedded", and therefore the apokoinou construction only apparently contradicts the generalization that fronting is a root phenomenon.

\subsubsection{A'-movement}

Fronting in Dutch shows all the properties of A'-movement. Thus, fronting is not strictly local (17a), fronting out of (extraposed) subject clauses is impossible (18a), and a fronted noun phrase licenses a parasitic gap (19a). In each case, fronting behaves exactly like wh-movement (cf. (17b),(18b), (19b)).
a. $\quad[\text { Dat boek }]_{\mathrm{i}} \quad$ denk ik that book think I "I think John already returned that book." which book think you heeft ]?
b. [Welk boek $]_{i}$ denk je $\quad\left[t_{i}\right.$ dat Jan $t_{i}$ al teruggebracht

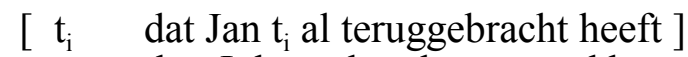 that John $t$ already returned has that John $t$ already returned


has

"Which book do you think John returned already?"
(18)
a.
$*$ [Dat boek $]_{i}$ is
het belangrijk
[dat Jan $\mathrm{t}_{\mathrm{i}}$ terug brengt] that book is
it important that John $t$ back brings
b. $\quad *[\text { Welk boek }]_{\mathrm{i}}$ is het belangrijk [dat Jan $\mathrm{t}_{\mathrm{i}}$ terug brengt]?
(19) a. [Dat boek] $]_{\mathrm{i}}$ heeft Jan [zonder $e_{\mathrm{i}}$ uit te lezen] $t_{\mathrm{i}}$ terug gebracht
that book has John without $e$ out to read $t$ back brought it important that John $t$ back brings "That book, John returned without finishing."
b. $\quad[\text { Welk boek }]_{\mathrm{i}}$ heeft Jan [zonder $e_{\mathrm{i}}$ uit te lezen] $t_{\mathrm{i}}$ terug gebracht ?
which book has John without $e$ out to read $t$ back brought
"Which book did John return without finishing?"

\subsubsection{D-word}

A fronted phrase may generally be accompanied by a demonstrative pronoun ( $d$-word) intervening between the fronted phrase and the finite verb:
a. Dat boek
dat heeft Jan gisteren snel terug gebracht
that book that has John yesterday quickly back brought
"John quickly returned that book yesterday."
b. Gisteren toen heeft Jan dat boek snel terug gebracht
yesterday then has John that book quickly back brought "Yesterday John quickly returned that book."

The d-word may not appear in any other position:

(21) a. *Dat boek heeft Jan gisteren dat snel terug gebracht that book has John yesterday that quickly back brought

b. $\quad *$ Dat boek heeft Jan dat gisteren snel terug gebracht that book has John that yesterday quickly back brought \#Gisteren heeft Jan toen dat boek snel terug gebracht yesterday has John then that book quickly back brought

((22) is only interpretably if toen "then" is taken to mean "consequently".)

The fronted elements dat boek dat "that book that" and gisteren toen "yesterday then" in

(20) may not appear as a sentence internal constituent:

*Jan heeft gisteren dat boek dat snel terug gebracht John has yesterday that book that quickly back brought \#Jan heeft gisteren toen dat boek snel terug gebracht John has yesterday then that book quickly back brought

(Again, (24) is interpreted with toen having a meaning independently from gisteren.)

Overdiep (1937:490) and Sassen (1953:212) coincide in estimating that around 80\% of the fronting cases in (spoken) Dutch involve only a d-word (i.e, without having a full phrase that the d-word resumes). Examples are given in (25) (cf. (20)):
a. Dat heeft Jan gisteren snel terug gebracht
that has John yesterday quickly back brought
"John quickly returned it yesterday."
b. Toen heeft Jan dat boek snel terug gebracht
then has John that book quickly back brought
"Then John quickly returned that book."

Not all fronted elements have a d-word to accompany them. We will return to the properties of d-words in section 2 . 


\subsubsection{Discourse-linking}

In his analysis of a corpus of spoken Dutch, Jansen (1981:82) found that in over 99\% of the fronting cases the fronted element is "activated by the discourse" (more exactly, the fronted material was found to be "more activated" than the material that was not fronted).

Jansen (1981:82) notes that sentences involving completely new material in fronted position were absent from his corpus, perhaps as a result of the circumstance that the texts studied were "quiet monologues" rather than heated discussions. It remains to be seen, however, whether discourse-linking would be less prominent in more agitated discourse (I share Jansen's (1981:83) impression that it would not). ${ }^{2}$

We will return to the discourse-relatedness of fronting in section 3.

\subsubsection{Intonation}

Fronting constructions in Dutch are not characterized by a particularly marked pitch accent on the fronted phrase. In fact, as Jansen (1978:101, 1981:82) and Kooij (1978:34) note, the fronted phrase is typically unstressed. ${ }^{3}$ Conversely, there is also no requirement on contrastively stressed constituents that they be fronted. In Dutch, phrases can be contrastively stressed in any position. Consequently, it is not excluded that the fronted phrase (or a subpart of the fronted phrase) has contrastive stress, but this cannot be regarded as a characteristic property of fronting constructions in Dutch.

This concludes the discussion of the properties of fronting in Dutch.

\subsection{Analysis}

The properties of fronting in Dutch discussed in section 1.1 suggest the following outline of an analysis of fronting in Dutch.

The inversion phenomenon is traditionally taken to involve verb movement to the complementizer position, $\mathrm{C}^{\circ}$, and movement of the fronted element to the specifier position of the projection of $\mathrm{C}^{\circ}, \mathrm{CP}:^{4}$

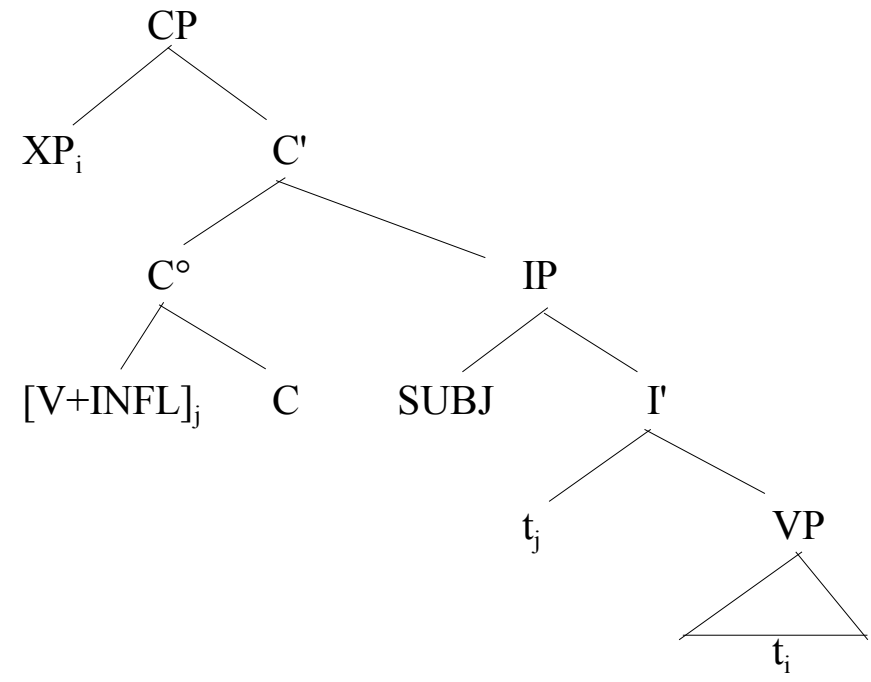

If movement is feature driven (see the Introduction), it must be the case that $\mathrm{C}^{\circ}$ hosts some feature that is checked by the fronted element (ignoring the issue of what triggers the verb movement to $\mathrm{C}$ for the moment). The fact that fronting is a root phenomenon suggests that the feature on $\mathrm{C}^{\circ}$ does not derive from subcategorization or selection by a higher head (unlike, for instance, the interrogative feature on $\mathrm{C}^{\circ}$ in embedded questions selected by verbs like wonder). 
However, the fact that fronting in Dutch is discourse-related suggests that the presence of the feature triggering fronting (if it exists) is present only if the sentence is discourse-related (in a way to be discussed in section 3 ).

The fact that fronting shows the properties of $A$ '-movement suggests one of the following two analyses. First, we might propose that the fronted element itself moves in a way comparable to wh-movement (27a). Second, we might propose that the fronted element is in fact basegenerated, and that some (empty) operator-like element is moved up front by way of whmovement (27b).

$$
\begin{aligned}
& \text { a. } \quad\left[{ }_{\mathrm{CP}} \mathrm{XP}_{\mathrm{i}}\left[\mathrm{IP}_{\mathrm{IP}} \ldots \mathrm{t}_{\mathrm{i}} \ldots\right]\right]
\end{aligned}
$$

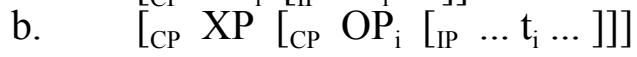

Both analyses have been proposed in the literature (cf. Chomsky 1977, Weerman 1989), and each suffices to account for the A'-movement properties of the fronting constructions.

The general possibility of having a $d$-word in fronting constructions in Dutch suggests that the second analysis, illustrated in $(27 \mathrm{~b})$, is correct. This implies that the operator-like element is not a wh-element but a demonstrative element, which is often realized overtly as the d-word.

Let us therefore investigate the status and function of the d-word. In what follows, I will refer to the fronted constituent as satellite, anticipating the correctness of the analysis in (27b).

\section{The d-word}

\subsection{Morphology}

The d-words appearing in fronting constructions in Dutch are distal demonstrative pronouns:

(28) Demonstrative pronouns in Dutch

\begin{tabular}{|c|c|c|}
\hline & proximal & distal \\
\hline person & deze & die \\
\hline singular object ${ }^{5}$ & dit & dat \\
\hline time & nu & dan, toen \\
\hline place & hier & daar \\
\hline manner ${ }^{6}$ & (zus) & zo \\
\hline
\end{tabular}

The proximal demonstrative pronouns cannot be used as a d-word in fronting constructions:

$$
\begin{array}{lll}
\text { Dit boek } & \text { dat } / * \text { dit } & \text { ken ik niet } \\
\text { this book } & \text { that } / \text { this } & \text { know I not }
\end{array}
$$

In (29), the proximal demonstrative is present in the satellite, yet the distal demonstrative must be used as the d-word. pronouns:

The paradigm of distal demonstratives is paralleled by the paradigm of interrogative

D-words vs. wh-words

$\begin{array}{lll} & \text { distal dem. } & \text { interrogative } \\ \text { person } & \text { die } & \text { wie } \\ \text { singular object } & \text { dat } & \text { wat } \\ \text { time } & \text { dan } & \text { wanneer } \\ \text { place } & \text { daar } & \text { waar } \\ \text { manner } & \text { zo } & \text { hoe }\end{array}$


The distal demonstrative pronouns and the interrogative pronouns are characterized by the alternation $d-w^{8}$

\subsection{Agreement}

The d-word agrees in $\varphi$-features with the satellite:
a. Jan die/*dat ken ik niet
John know I not
b. Dat boek dat/*die ken ik niet
that book know I not

A nonagreeing d-word appears when the satellite corresponds to the predicate of a Small Clause (32a), or to the subject of a Small Clause, where the predicate is a second order predicate (32b) (cf. De Rooy 1970, Rullmann and Zwart 1996):
a. Een echte ambtenaar dat $/ *$ die a true civil servant
vind ik consider I
$[\mathrm{sC}$
Jan $e]$ "I consider John to be a true civil servant."
b. Jan dat is [sc $e$ de beste/*goed ]
John is the best one/good

Rullmann and Zwart (1996) argue that in both sentences of (32), the gap (e) is of the semantic type $<e, t>$, and that in that case the d-word must come out as the neuter form $d a t{ }^{9}$

These examples suggest that it is actually the semantic function of the gap that determines the morphology of the d-word, and that the agreement between the d-word and the satellite in (31) is in fact secundary.

The agreement facts can be summarized as follows: ${ }^{10}$

(33) a. If the gap in fronting constructions is of the type $<e, t>$, the $d$-word is $d a t$

b. $\quad$ Elsewhere, the d-word agrees in $\varphi$-features with the satellite.

I take the agreement facts to indicate that the gap in fronting constructions is bound by the dword, not by the satellite. In other words, these facts suggest that the analysis in (27b) is correct.

Other arguments supporting the analysis in $(27 \mathrm{~b})$ are that a d-word seems to be generally possible (see section 2.4), whereas the satellite appears to be absent in a large majority of the fronting cases in spoken Dutch (around 80\%, according to Overdiep (1937) and Sassen (1953)). Assuming that the operator may be an overt or empty d-word, the analysis in (34) suffices to capture this state of affairs: ${ }^{11}$

$$
\left(\left[\begin{array}{lll}
\mathrm{CP} & \mathrm{XP}
\end{array}\right)\left[\mathrm{CPP}_{\mathrm{CP}} \mathrm{OP}_{\mathrm{i}}\left[\begin{array}{llll}
\mathrm{IP} & \ldots & \mathrm{t}_{\mathrm{i}} \ldots
\end{array}\right]\right)(]\right)
$$

(34) is identical to (27b), allowing for the optional absence of a satellite. The agreement generalization in (33) supports the analysis in (34), which I will from now on assume to be correct.

\subsection{Discourse-linking}

The presence of the d-word appears to be discourse related. This can be concluded from examples like the following:
a. Iedereen
everyone
b. Iedereen
everyone
(*die) is sterfelijk
(die) was er
was there 
In (35a), the universal quantifier iedereen "everyone" has an unrestricted domain: its domain of reference is the entire universe, not delimited by the discourse situation. In this context, no dword can appear. In (35b), on the other hand, the domain of reference is not the entire universe, but the set of people expected to be present. Here, the discourse situation restricts the domain of the universal quantifier, and the d-word may appear.

The connection with the discourse can also be established by the satellite itself:
a. Overal (??daar) is ellende
b. Overal waar je kijkt everywhere where you look
"Everywhere you look there is misery."
(daar) is ellende
is misery

In (36a), the domain of overal "everywhere" is unlimited, and the d-word is bad. In (36b), the domain of overal is restricted by waar je kijkt "where you look", and the d-word is possible.

These observations suggest that the d-word may appear whenever the satellite is discourse-linked.

As mentioned in section 1.1.4, Overdiep (1937:491) and Sassen (1953:212) estimate that in $80 \%$ of the fronting cases in Dutch, no satellite is present. ${ }^{12}$ In those cases, the $\mathrm{d}$-word is not related to a discourse-linked satellite, but is itself discourse-linked.

The generalization that emerges is that the d-word is always discourse-linked, either directly, without a satellite, or indirectly, by being related to the satellite.

\subsection{Fronting without a d-word}

If fronting in Dutch always involves a (possibly empty) d-word, it will be relevant to consider the properties of fronting constructions in which no d-word occurs.

\subsubsection{General absence}

Fronting constructions without a d-word are of the following types:

a) With discourse particles in first position

The particles in question are monosyllabic words like $n u$ "(nontemporal) now", dus "so, therefore", dan "then, in that case, next", toch "yet". These particles typically connect the sentence to previous discourse in one way or another. An example is given in (37):
A: Ik begrijp "Chapter Four" niet
"I don't understand "Chapter Four"."
B: $\mathrm{Nu}$ schrijft Chomsky ook wel onduidelijk
now writes Chomsky also rather unclear
"Well, Chomsky's writing is unclear also."

These particles are never followed by a d-word.

b) With personal pronouns and anaphors in first position

The absence of d-words with fronted personal pronouns is illustrated in (38):

\begin{tabular}{|c|c|c|}
\hline (38) & $\begin{array}{l}\text { Hem (??die) } \\
\text { him "Him Idon't know" }\end{array}$ & $\begin{array}{l}\text { ken ik niet } \\
\text { know I not }\end{array}$ \\
\hline b. & $\begin{array}{l}\text { "Him, l don t know. } \\
\text { Zichzelf } \\
\text { himself }\end{array}$ & $\begin{array}{l}\text { haat hij niet } \\
\text { hates he not }\end{array}$ \\
\hline
\end{tabular}


However, the absence of a d-word with fronted personal pronouns does not appear to be absolute (cf. also Jansen 1981:179). This can be seen in constructions where the gap is in the complement of a preposition. Preposition stranding in Dutch is only possible when the extracted element has locative morphology (the feature [+R] of Van Riemsdijk 1978):

$$
\begin{array}{ll}
\text { Jan ??(daar/*die) } & \text { heb ik een hekel aan } \\
\text { John } & \text { have I a dislike to } \\
\text { "John I dislike." } &
\end{array}
$$

As can be seen, in (39) the d-word is forced to be present, and, because of the preposition stranding, it has to be a locative d-word. This is also the case when the satellite is a personal pronoun or anaphor:

(40) a. Hem ??(daar/*die) heb ik een hekel aan

"Him I dislike."

b. Zichzelf ??(daar/*die) heeft hij een hekel aan "Himself he dislikes."

Thus, with pronouns and anaphors the d-word is not prohibited. When the grammatical context requires a d-word, as in (40) it appears. As for (38), we may conclude that the d-word is either not present at all, or present but not spelled out for some reason.

c) With adverbials in the first position

As Koster (1978:207) notes, adverbs are not resumed by a d-word:

$$
\begin{array}{ll}
\text { Waarschijnlijk } & \text { heeft Jan het boek terug gebracht } \\
\text { probably } & \text { has John the book back brought }
\end{array}
$$

However, it is not clear that adverbs in principle resist insertion of a d-word. Vanacker (1980) shows that in East Flemish dialects a d-word die is used with various types of preposed adverbials (cf. also Weijnen 1966:309): ${ }^{13}$

$$
\begin{aligned}
& \text { Bijgevolg die moet da verwijderd worden } \\
& \text { as a result } \\
& \text { "Therefore that has to be removed." }
\end{aligned}
$$

East Flemish

Also, in Standard Dutch, temporal adverbials may be resumed by dan or toen (see also Sassen 1953:224):
a. Morgen
(dan) ga ik naar huis
tTomorrow
go I to house
b. Gisteren
yesterday
"Yesterday

Again, it is not clear that the absence of the d-word in (41) is a fact of great significance.

What can we conclude from the more or less general absence of d-words in these constructions?

In the case of the discourse particles, it seems that the function of discourse-linking is performed by the particles themselves, and that no d-word needs to be moved or inserted in connection with the discourse-relatedness of the construction. Possibly, the particles are inserted in the position of the operator indicated in (34).

In the case of the pronouns, it seems that the d-word is not so much absent as preferably empty. Whenever the syntactic configuration requires the presence of a d-word, it shows up, even when the satellite is a pronoun. 
In the case of the adverbs, the dialect facts suggest that at least for a number of adverbial elements, a d-word is not in principle excluded. This makes it possible to hypothesize that in Standard Dutch, fronted adverbs are standardly resumed by an empty d-word.

In general, there appears to be no evidence that speaks against an analysis of the relevant constructions in terms of the structure in (34).

\subsubsection{Optional presence}

The phenomenon of fronting with a seemingly redundant d-word very much appears to be a fact of spoken language. It is easy to create constructions in which a direct object is fronted without a d-word present:

$$
\begin{aligned}
& \text { Dat boek ken ik niet } \\
& \text { that book know I not } \\
& \text { "I don't know that book." }
\end{aligned}
$$

However, the studies of spoken Dutch by Jansen $(1978,1981)$ and Kooij (1978) suggest that fronting of arguments is in fact very rare. In my intuition, a construction with a d-word would be much preferred in the appropriate discourse situation:

$$
\begin{aligned}
& \text { A. Heb jij "Oorlog and Vrede" gelezen? } \\
& \text { "Have you read "War and Peace"?" } \\
& \text { B. Nee, dat boek ?(dat) ken ik niet. } \\
& \text { no that book that know I not }
\end{aligned}
$$

Nevertheless, inasmuch as fronting constructions without a d-word can be produced, we have to conclude that the presence of the $\mathrm{d}$-word is at best optional.

Again, this leads to two possible analyses. In one, the d-word is optionally present. In another analysis, the d-word is always present, but optionally spelled out.

If the d-word is not always present, we may expect constructions with and without a dword to have different properties. For example, Cinque (1990) shows that in Italian dislocation constructions, it makes quite a difference whether the dislocated phrase is resumed by a clitic (clitic left dislocation) or not (left dislocation). For example, left dislocation constructions involve only noun phrases, whereas clitic left dislocation constructions may involve any type of phrase; left dislocation takes place in root clauses only, whereas clitic left dislocation takes place in root clauses and embedded clauses; there can be no multiple left dislocation, but multiple clitic left dislocation is grammatical; left dislocation is not sensitive to island conditions and shows no connectivity effects, whereas with clitic left dislocation, it is again the opposite; etc.

Interestingly, none of these criteria appear to distinguish fronting cases with a d-word from fronting cases without a d-word in Dutch. This suggests that the d-word is in fact always present, though not always spelled out.

In the next section, we will consider the discourse functions of fronting in Dutch. Again, it appears to be the case that constructions with and without a d-word serve the same discourse functions (albeit that constructions with a d-word appear to be more felicitous, and more common in spoken language).

\section{The discourse functions of fronting in Dutch}

This section is based on Prince's (this volume) analysis of the discourse functions of left dislocation and topicalization in English. We will argue that the same discourse functions are present in fronting in Dutch. There is one difference between English and Dutch, though. In Dutch, fronting can always involve insertion of a d-word between the fronted phrase (the satellite) and the finite verb, whereas in English, this is never the case.

Prince (this volume) distinguishes the following types of fronting in English: 
1. Left Dislocation
a) Simplifying Left Dislocation
b) Poset Left Dislocation
c) Resumptive Left Dislocation

2. Topicalization

These fronting types are discussed in the following subsections.

\subsection{Left Dislocation}

\subsubsection{Simplifying Left Dislocation}

A Simplifying Left Dislocation involves discourse-new entities that are removed from a position disfavored for discourse-new entities. Fronting creates a separate processing unit for these entities. After that, "they have become discourse-old, [and] they (or, rather, the pronouns which represent them) may comfortably occur in their canonical positions within the clause." (Prince, this volume, (9)).

By way of illustration, consider the data in (47):

"Two of my sisters were living together on 18th Street. They had gone to bed, and this man, their girlfriend's husband, came in. He started fussing with my sister and she started to scream. The landlady, she went up, and he laid her out. (...)" (Prince, this volume, (4))

The subject position, where the pronoun she occurs, disfavors discourse-new information. The landlady is fronted and becomes discourse-old, so that the subject position can be occupied by a (inherently discourse-old) pronoun, referring to the fronted noun phrase.

In Dutch, it appears that Simplifying Left Dislocation never involves a personal pronoun. Instead, the fronted noun phrase is taken up by a d-word, which is itself fronted: ${ }^{14}$

$$
\begin{aligned}
& \text { (in the same context as (47)) } \\
& \text { De hospita die/*zij kwam naar boven } \\
& \text { the landlady that/she came to upstairs } \\
& \text { "The landlady, she went up." }
\end{aligned}
$$

Apart from this difference, it seems that (spoken) Dutch employs the same strategy of removing discourse-new material from positions that disfavor discourse-new material by way of fronting.

This can be seen most clearly in the Apokoinou construction (cf. section 1.1.2). Consider the following example: ${ }^{15}$

$\mathrm{Na}$ dagen reizen kwamen we bij een smerige rivier. Toen stonden after days traveling came we at a filthy river. then stood

daar een paar vrouwen die stonden daar de was te doen. there a couple women they stood there the laundry to do

"After days of traveling we arrived at a filthy river. A couple of women, they were doing the laundry over there."

In (49), een paar vrouwen die starts off a new sentence. Without apokoinou, the sentence would have looked like (50): 
Toen stonden daar een paar vrouwen de was te doen. then stood there a couple women the laundry to do

In (50), een paar vrouwen "a couple of women", which represents discourse-new entities, appears in the subject position, a position that disfavors discourse-new material. One way of removing the discourse-new material from the subject position would be to front it, yielding (51) (structurally the same as (48)):

Een paar vrouwen die stonden daar de was te doen.

a couple of women they stood there the laundry to to

In (49), however, this is impossible, because the first position is already occupied by the discourse-linking adverb toen "then". The only way to achieve Simplifying Left Dislocation, then, is to treat the subject een paar vrouwen as if it were the first constituent, by inserting a dword and repeating the finite verb after it.

It appears to me that apokoinou constructions in spoken Dutch generally have these characteristics: the element starting off the new sentence is discourse-new, and the first position of the sentence is already occupied by a discourse-linking adverb or a pronoun (cf. Jansen 1981:198ff).

Other clear cases of Simplifying Left Dislocation in Dutch involve possessives. If the possessor noun phrase is discourse-new, it is preferably fronted, and a d-word is inserted:

Er was een hoop herrie in de stad. Een politieman daar hebben ze there was a lot-of moise in the city. a cop there have they

het huis van verbrand.

the house of burned-down

"There was a lot of turmoil in town. They burned a cop's house."

(\#Ze hebben het huis van een politieman verbrand.)

they have the house of a cop burned-down

In conclusion, Simplifying Left Dislocation in Dutch involves fronting, like English, and, unlike English, a process of d-word insertion (or, d-word fronting). ${ }^{16}$

\subsubsection{Poset Left Dislocation}

Poset Left Dislocation involves discourse-old material. Prince (this volume) gives the following characterization of Poset Left Dislocation: "A 'Poset' Left-Dislocation serves to trigger an inference on the part of the hearer that the entity represented by the initial [noun phrase] stands in a salient partially-ordered set relation to some entity or entities already evoked in the discourse-model." (Prince, this volume, (11)). ${ }^{17}$

The core case of a Poset left dislocation is formed when the fronted element is already evoked in the discourse-model (i.e., the partially-ordered set relation is the identity relation), but more subtle cases are when the fronted element is a subtype of something that is previously evoked in the discourse-model, or is a part of something that is previously evoked in the discourse-model. For example, when the discussion is about what happened at school in the various grades, and one would say something like (53), the fronted constituent in de zesde klas "in the sixth grade" stands in a partially-ordered set relation to the entity "grades at school":

In de zesde klas werd dat allemaal anders

in the sixth grade became that all different

"In the sixth grade, all that changed."

In (53), the fronted constituent does not count as discourse-new, even though the sixth grade itself had not been mentioned yet in the discourse. 

others:

Prince (this volume) illustrates Poset Left Dislocation with the following example, among

She had an idea for a project. She's going to use three groups of mice. One, she'll feed them mouse chow, just the regular stuff they make for mice. Another, she'll feed them veggies. And the third she'll feed junk food. (Prince, this volume, (10f))

In (54), only one and another appear in Poset Left Dislocation. Again, resumption by a pronounin-situ is a characteristic of dislocation, and in Dutch the pronoun is replaced by a fronted dword. The fronting in the final sentence, without a resumptive pronoun, is discussed in section 3.2 as topicalization.

The translation of (54) into Dutch yields (55), where the left dislocated element is a satellite, resumed by a d-word:

Ze had een idee voor een project. Ze wou drie groepen muizen nemen. she had an idea for a project. she wanted three groups mice take

De eerste die wou ze muizevoer geven (..).

the first that wanted she mouse-chow give

De tweede die wou ze groente geven.

the second that wanted she vegetables give

En de derde die wou ze junkfood geven.

and the third that wanted she junkfood give

Again, the d-word does not seem obligatory, but its presence appears to be highly preferred. (Note that in the topicalization case, a d-word can appear, whereas in English, the resumptive pronoun is absent.)

In less subtle cases, where the fronted element is already present in the discourse, fronting appears to be near obligatory:
A.
Jan is ontslagen
John is fired
B. a. Dat wist ik niet
that know I not
b. $\quad$ \#Ik wist dat niet
I knew that not

\subsubsection{Resumptive Left-Dislocation}

Resumptive Left-Dislocation in English occurs when the gap associated with the fronted element is in an island, i.e. in a local domain that prohibits extraction:

$$
\text { My first book, I paid half of each trick to the person who gave *(it) to me }
$$

Prince (this volume, section 4.2) argues that this is in fact a case of topicalization in disguise (for topicalization, see section 3.2).

This type of construction does not appear to occur in Dutch, except, possibly, in a Hanging Topic construction (which does not seem prominent in spoken Dutch, see note 14).

The ubiquity of d-words in left-dislocation constructions in Dutch suggests an explanation for the absence of resumptive left dislocation. If left dislocation in Dutch involves d-word fronting, and d-word fronting is standard A'-movement (see section 1.1.3), fronting out of an island automatically yields an ungrammatical construction.

This explanation implies that in (57), the first constituent has not been moved, but is base generated in sentence initial position. Otherwise, we could not explain the absence of resumptive left dislocation in Dutch in terms of conditions on movement. We would have to say that the 
movement of the full noun phrase in (57) would be allowed, whereas a similar movement of a full noun phrase or d-word would not be allowed in Dutch. On the other hand, if we assume that satellites are base-generated in both English and Dutch, and that only Dutch has d-word movement, the absence of resumptive left-dislocation in Dutch follows from standard locality conditions on (d-word) movement.

\subsection{Topicalization}

Topicalization, as defined by Prince (this volume, section 4), shares with Poset Left Dislocation the characteristic that the fronted element triggers an inference on the part of the hearer that the entity it represents stands in a salient partially-ordered set relation to some entity or entities previously evoked in the discourse-model. It differs from Poset Left Dislocation, on the other hand, in that it forces the hearer to structure the proposition into a focus and a focus frame.

The focus and focus frame are construed on the basis of intonational cues. Topicalization involves a stressed constituent further down in the sentence (i.e., not the fronted element itself). The focus frame is construed on the basis of the partially-ordered set relation that the hearer infers from the fronted constituent. The stressed constituent further down in the sentence is the focus, i.e. it provides the missing information needed in the focus frame.

In the example (54), when the third is uttered, an inference is triggered that there is an experiment with three groups of mice going on, each of which gets some kind of food. This is the focus frame. Junkfood is stressed, and it provides the missing information, namely the kind of food that is to be fed to the third group of mice. I refer to Prince (this volume, section4.1) for further discussion of the processes and inferences involved.

In Dutch, as illustrated in (55), topicalization may involve fronting, and, optionally as always, insertion of a d-word. ${ }^{18}$

\subsection{Discussion}

Fronting in Dutch serves the same discourse functions as fronting in English. Simplifying somewhat, we can say that information presented by the fronted constituent is either "old" in the sense of triggering a "poset" inference, or new.

We may have to modify "new" somewhat here. New information can be either "central" or "peripheral", where central new information is what the sentence is intended to convey, and peripheral new information is information which is itself new, but is needed to convey the central new information. In (47), the central new information is that the landlady went up (and was laid out again), and the presence of the landlady in the situation is subsidiary, peripheral new information. It seems that the new information presented by a fronted constituent is always peripheral rather than central.

Crucial for our purposes is that fronting in Dutch appears to involve two processes: a) the introduction of a satellite, and b) fronting of a d-word. From a functional perspective, it seems that the introduction of a satellite is sufficient for the purpose of discourse-linking of the sentence. This is the process that English and Dutch have in common. The second process, fronting of a d-word, is present in Dutch only. It does not appear to serve a particular discourse related function, even though the occurrence of the process is clearly discourse-related.

I would like to propose that a necessary condition for discourse-linking of a sentence is that the root of the sentence is marked by a syntactic feature expressing discourse-linking, and that d-word fronting is an autonomous syntactic process, which is best described in terms of feature checking (where the relevant feature must be discourse-related in some sense to be made precise) and parametrization (as the process is present in Dutch and absent in English, without apparent effect on the discourse function of the constructions involved).

\section{Discourse-linking and feature checking}

The comparison of English and Dutch in section 3 suggests that fronting consists of a (possibly universal) process "introduce satellite" and a (parametrized) process "move d-word".

I would like to propose the following description of this state of affairs. 
The satellite is base generated as an adjunct to the root node of the sentence. The satellite is linked to the discourse in the ways discussed in section 3. Let us assume that adjunction of a satellite implies that the root node of the sentence (i.e., the sentence itself) has a feature that expresses its discourse-relatedness. I will refer to this feature as [D].

The root node is taken to be $\mathrm{CP}$ (the complementizer phrase), so that the feature [D] must originate in the head of $\mathrm{CP}, \mathrm{C}^{\circ}$.

We may now propose that the feature [D] needs to be licensed in a specifier-head configuration (cf. Chomsky 1986, 1995). It therefore attracts an XP with the required feature content to its specifier position. In Dutch, the XP moving to the specifier position of CP is the d-word:

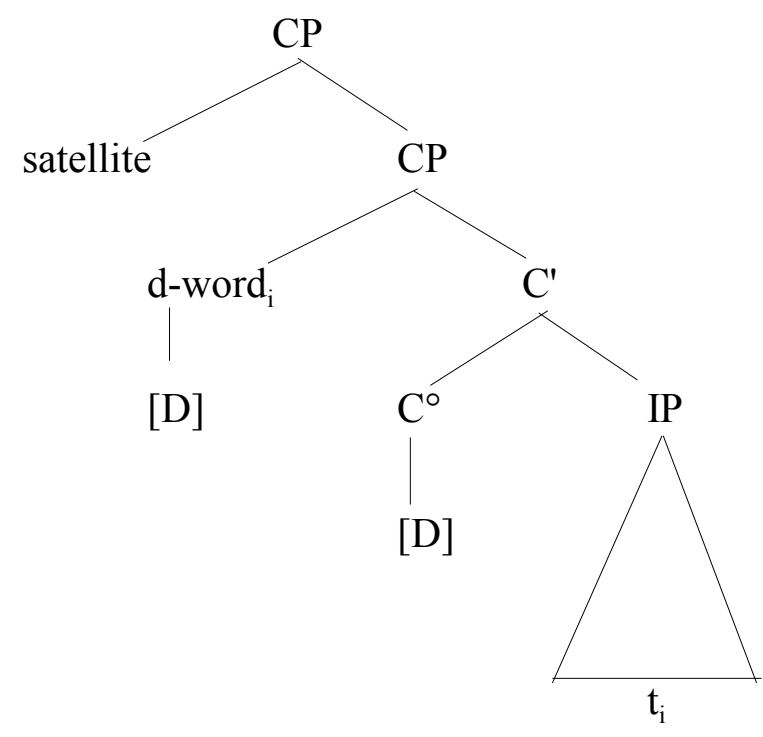

The description of fronting in terms of feature checking is entirely parallel to the standard description of wh-movement (cf. Chomsky 1986, Rizzi 1990). In the standard description of whmovement, the head of $\mathrm{CP} \mathrm{C}^{\circ}$ has a [WH] feature that is licensed in a specifier-head relation with an XP carrying the [WH] feature (i.e., a wh-phrase):

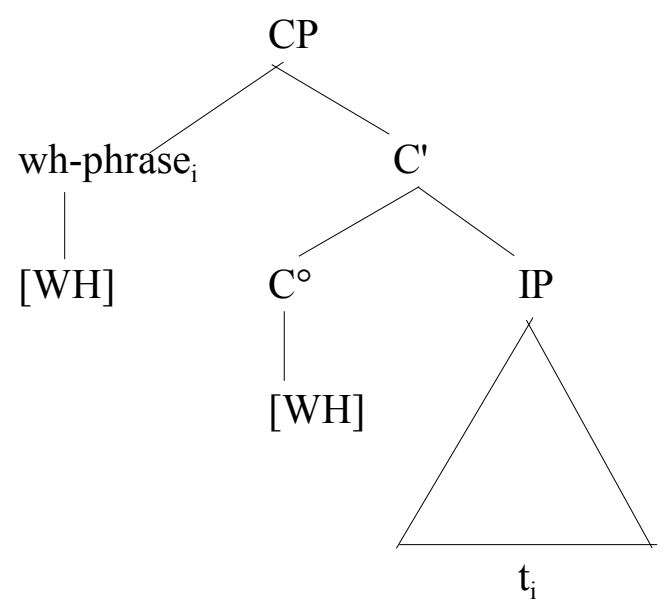

Above, we have seen two aspects in which d-words are comparable to wh-phrases. First, d-words move by A'-movement like wh-phrases (section 1.1.3). Second, d-words enter into a morphological alternation with interrogative pronouns, characterized by the alternation $d-w$ (section 2.1).

Fronting constructions are also comparable to wh-constructions in that the features involved (the [D] feature and the [WH] feature) are not inherent features of clauses but features imposed "from the outside". The only reason these features are present on $\mathrm{C}^{\circ}$ is that the speaker intends to produce a sentence that is discourse-linked or interrogative. In this respect, the $[\mathrm{D}] /[\mathrm{WH}]$ features differ from the features involved in the syntactic licensing of subjects and 
objects (Case/Agreement features, cf. Chomsky 1993), which are taken to be present independently of the intentions of the speaker.

A difference between fronting constructions and wh-constructions is that whconstructions (as currently understood) do not involve a satellite. Recall, however, that an estimated $80 \%$ of the fronting constructions in Dutch are without a satellite (see section 1.1.4 and references cited there). This implies that the satellite is not crucial to discourse-linking, and that the presence of the feature [D] on $\mathrm{C}^{\circ}$ depends solely on the intention of the speaker to produce a discourse-related sentence. The satellite appears to be just a mediator between the sentence and the discourse context. ${ }^{19}$

The difference between English and Dutch can be described in a standard way (cf. Chomsky 1993): the [D] feature is "strong" in Dutch and "weak" in English. Therefore in Dutch it forces the d-word to move to Spec,CP overtly, whereas in English, the process of d-word movement is completely absent (i.e. the [D] feature has no observable effect). ${ }^{20}$

Summarizing, the relation between discourse considerations and syntactic considerations in Dutch appears to be as follows:

$\begin{array}{lll}\text { a. } & \text { Discourse } & \text { requires } \\ \text { b. } & {[+\mathrm{D}]} & \text { triggers }\end{array}$

\author{
a $\mathrm{CP}$ headed by a $[+\mathrm{D}] \mathrm{C}^{\circ}$ \\ movement of a d-word
}

\title{
5. Conclusion
}

In this article I have taken a closer look at fronting in Dutch. I have concluded that the d-word that is optionally present in fronting constructions in Dutch moves to the specifier position of CP, triggered by a feature $[\mathrm{D}]$ on $\mathrm{C}^{\circ}$ which expresses the discourse-relatedness of the sentence. The fronted constituent itself is analyzed as a satellite, base-generated in a position adjoined to the root node of the sentence.

If this analysis is correct, it sheds light on the division of labor between discourse factors and factors of autonomous syntax. The former require the presence of a syntactic feature [D] on the highest functional head of the sentence, whereas the latter trigger overt movement in a subset of the languages that employ the feature [D].

This analysis also suggests that it would be premature to relegate apparently optional movement processes to a "stylistic" component of the grammar. The optionality of fronting in Dutch lies in the intention of the speaker to express the way his sentence is linked to the discourse. Beyond that, processes of autonomous syntax take over.

\section{References}

Cardinaletti, A. 1990. "Subject/Object Asymmetries in German Null-Topic Constructions and the Status of SpecCP." In J. Mascaró and M. Nespor, eds., Grammar in Progress. GLOW Essays for Henk van Riemsdijk. Foris, Dordrecht, pp. 75-84.

Chomsky, Noam. 1977. “On Wh-Movement.” In P. Culicover, T. Wasow, and A. Akmajian, eds., Formal Syntax. Academic Press, New York, pp. 71-132.

Chomsky, Noam. 1981. Lectures on Government and Binding. Foris, Dordrecht.

Chomsky, Noam. 1986. Barriers. MIT Press, Cambridge.

Chomsky, Noam. 1993. "A Minimalist Program for Linguistic Theory." In K. Hale and S.J. Keyser, eds., The View from Building 20. Essays in Linguistics in honor of Sylvain Bromberger. MIT Press, Cambridge, pp. 1-52.

Chomsky, Noam. 1995. "Categories and Transformations." In N. Chomsky, The Minimalist Program. MIT Press, Cambridge, pp. 219-394. 
Cinque, Guglielmo. 1990. Types of A'-Dependencies. MIT Press, Cambridge.

De Rooy, Jaap. 1970. “Onzijdige voornaamwoorden en het naamwoordelijk gezegde.” De Nieuwe Taalgids 63, 181-186.

De Vries, Wobbe. 1910-1911. Dysmelie. Opmerkingen over syntaxis. Program of the Municipal Gymnasium of Groningen.

Den Besten, Hans. 1977. "On the Interaction of Root Transformations and Lexical Deletive Rules." Ms. MIT. Published in W. Abraham, ed., On the Formal Syntax of the Westgermania. John Benjamins, Amsterdam, 1983, pp. 74-131.

Epstein, Samuel David. 1995. "Un-Principled Syntax and the Derivation of Syntactic Relations." Ms., Harvard University.

Hooper, Joan B. and Sandra A. Thompson. 1973. "On the Application of Root Transformations." Linguistic Inquiry 4, 465-497.

Jansen, Frank. 1978. "Sentence Initial Elements in Spoken Dutch." In W. Zonneveld, ed., Linguistics in the Netherlands 1974-1976. Peter de Ridder Press, Lisse, pp. 102-108.

Jansen, Frank. 1981. Syntaktische konstrukties in gesproken taal. Huis aan de drie grachten, Amsterdam.

Kooij, Jan. 1978. "Fronting in Dutch.” In F. Jansen, ed., Studies on Fronting. Peter de Ridder Press, Lisse, pp. 29-51.

Koster, Jan. 1975. “Dutch as an SOV Language.” Linguistic Analysis 1, 111-136.

Koster, Jan. 1978. Locality Principles in Syntax. Foris, Dordrecht.

Koster, Jan. 1987. Domains and Dynasties. The Radical Autonomy of Syntax. Foris, Dordrecht.

Neeleman, Ad. 1994. "Scrambling as a D-structure Phenomenon." In N. Corver and H. van Riemsdijk, eds., Scrambling. Mouton De Gruyter, Berlin, pp. 387-429.

Overdiep, Gerrit Siebe. 1937. Stilistische grammatica van het Moderne Nederlandsch. First edition. Tjeenk Willink, Zwolle.

Partee, Barbara. 1987. "Noun Phrase Interpretation and Type Shifting Principles." In J. Groenendijk, D. de Jongh, and M. Stokhof, eds., Studies in Discourse Representation and Generalized Quantifiers. Foris, Dordrecht.

Prince, Ellen F. This volume. "On the Limits of Syntax, with reference to Left-Dislocation and Topicalization."

Rizzi, Luigi. 1990. “Speculations on Verb Second.” In J. Mascaró and M. Nespor, eds., Grammar in Progress. GLOW Essays for Henk van Riemsdijk. Foris, Dordrecht, pp. 375-386.

Rochemont, Michael S. This volume. "Phonological Focus and Structural Focus."

Rullmann, Hotze and Jan-Wouter Zwart. 1996. “On Saying Dat.” In R. Jonkers, E. Kaan, and A. Wiegel, eds., Language and Cognition 5. Yearbook 1995 of the Research Group for Theoretical and Experimental Linguistics of the University of Groningen. Department of Linguistics, University of Groningen, pp. 179-194.

Sassen, Albert. 1953. Het Drents van Ruinen. Van Gorcum/Hak/Prakke, Assen. 
Van Riemsdijk, Henk. 1978. A Case Study in Syntactic Markedness. Foris, Dordrecht.

Van Riemsdijk, Henk and Frans Zwarts. 1974. "Left Dislocation in Dutch and the Status of Copying Rules." Ms., MIT/University of Amsterdam.

Vanacker, Valeer F. 1980. “Een Vlaams adverbiaal steuntje.” In J. Kruijsen, ed., Liber Amicorum Weijnen. Van Gorcum, Assen, pp. 73-78.

Vercoullie, Jozef. 1925. Beknopt Etymologisch Woordenboek der Nederlandsche Taal. Third edition. Van Rysselberghe \& Rombaut, Gent.

Weerman, Fred. 1989. The V2 Conspiracy. Foris, Dordrecht.

Weijnen, Anton A. 1966. Nederlandse Dialectkunde. Van Gorcum, Assen.

Zwart, C. Jan-Wouter. 1993. Dutch Syntax. A Minimalist Approach. Dissertation, University of Groningen.

Zwart, C. Jan-Wouter. 1996. Morphosyntax of Verb Movement. A Minimalist Approach to the Syntax of Dutch. Kluwer, Dordrecht.

\section{Notes}

1. This is not to say that all constructions in which some constituent precedes the finite verb involve movement of that constituent to the left. Below, I will argue that YP in (7) has been moved to the left only if it is a demonstrative element (d-word). In all other cases, YP appears to be base-generated in the first position.This is not to say that all constructions in which some constituent precedes the finite verb involve movement of that constituent to the left. Below, I will argue that YP in (7) has been moved to the left only if it is a demonstrative element (d-word). In all other cases, YP appears to be basegenerated in the first position.

2. A non-discourse-linked example, made up by the author, would be (ib):

(i)

$\begin{array}{llllll}\text { a. } & \text { Ik } & \text { word } & \text { er } & \text { gek van } \\ & \text { I } & \text { become } & \text { there } & \text { crazy of } \\ \text { b. } & \text { Gek } & \text { word ik } & \text { er } & \text { van! } \\ & \text { crazy } & \text { become I } & \text { there } & \text { of }\end{array}$

"It's driving me crazy!"

In both sentences in (i), the predicative adjective gek is the only element carrying pitch accent, (ib) being only slightly more emphatic. The fronted phrase in (ib) does not appear to be discourse related in any way. Other examples, provided by a reviewer are: a. De buren moeten we nog inlichten! "We still have to notify the neighbors!"
b. Je paspoort moet je niet vergeten! Your passport must je not forget "Don't forget your passport!"

In the intended non-discourse-linked readings, only the first constituents (de buren "the neighbors" and je paspoort "your passport") receive any kind of pitch accent. In this respect these constructions are different from the fronting constructions discussed here (see section 1.1.6). Also, it seems that with this intonational pattern, a d-word is excluded: 
(iii) a.

$$
\text { \#Je PASpoort dat moet je niet vergeten }
$$

your passport that must you not forget

(only contrastive: it's your passport that you shouldn't forget)

b. Je PASpoort dat moet je NIET verGEten

your passport that must you not forget

"You should not forget your passport."

3. In contrast, the fronting cases discussed in the previous footnote are stressed. This suggest that they involve a different type of phenomenon.

4. This analysis goes back to Koster (1975) and Den Besten (1977). Before Chomsky (1986), the movement of the fronted element is not described as movement to a specifier position, but as movement to a generic sentence initial position, COMP, which also hosts the inverted verb. Traditionally, INFL is situated to the right of the VP in the analysis of Dutch syntax, so that the verb second phenomenon in subject initial main clauses (cf. (1)) also involves verb movement to $\mathrm{C}$ and "topicalization" of the subject. For extensive discussion of this traditional analysis, see Zwart $(1993,1996)$. The issue is not relevant for the problems at hand.

5. Demonstrative pronouns referring to plural objects are left out of consideration here. They are deze (proximal) and die (distal). There does not seem to be an interrogative pronoun for plural objects in Dutch (thus, wat wil je "what do you want" does not have the interpretation "which two things do you want"), apart from elliptic welke "which (things)".

6. Demonstrative pronouns referring to plural objects are left out of consideration here. They are deze (proximal) and die (distal). There does not seem to be an interrogative pronoun for plural objects in Dutch (thus, wat wil je "what do you want" does not have the interpretation "which two things do you want"), apart from elliptic welke "which (things)".

7. wanneer $<$ wan + eer ("when" + "earlier") (Vercoullie 1925:383).

8. The initial $h$ - of the manner interrogative pronoun hoe is etymologically related to the initial $w$ - in the remaining interrogative pronouns, both deriving from $h w$-.

9. This does not necessarily imply that the satellite Jan in (32b) is of type $<e, t>$ also. Rullmann and Zwart (1996:192) however argue that it may be, as a result of the type shifting operation IDENT of Partee (1987), which lifts a noun phrase of type $<e>$ to type $<e, t>$ (i.e. it maps an individual onto the singleton set containing it).

10. As suggested by a reviewer, the disjunction in (33) can be removed if elements of the type $<e, t>$ have neuter singular $\varphi$-features.

11. With an empty d-word, (34) also suffices to describe the topic-drop phenomenon discussed by Cardinaletti (1990):

(i) (Dat) ken ik niet

that know I not

"I don't know that."

12. To be more exact, Overdiep and Sassen argue that in $80 \%$ of the fronting cases the first constituent is a monosyllabic d-word or adverb (like dan "then", toen "then", daar "there", $n u$ "now") which, as Overdiep says "in most cases refer to the contents of a previous sentence" (1937:490). Sassen adds that in his study of the dialect of Ruinen, $11.5 \%$ of the fronting cases without satellite involve a pronoun as the first constituent. As pronouns are inherently discourse related, both observations confirm the generalization that the fronting is discourse-related. 
13. The d-word die cannot be used independently, i.e. without a satellite (Vanacker 1980:77).

14. Van Riemsdijk and Zwarts (1974) discuss so-called Hanging Topic constructions, illustrated in (i), which look like English Simplifying Left Dislocation:

(i) Die vent -- ik kan hem niet uitstaan

that guy -- I can him not stand ("That guy, I can't stand him.")

However, Jansen (1981:176) has not found constructions of this type in his corpus of Spoken Dutch utterances. Also, it is not clear whether the construction in (i) is actually Simplifying Left Dislocation. It appears that the fronted noun phrase die vent "that guy" is already present in the discourse. In addition, the Hanging Topic construction seems to require a heavy pause, unlike Simplifying Left Dislocation.

In situations where a d-word is impossible, it seems that it is possible to use a personal pronoun in situ. This occurs only when the discourse-new material is inside an adjunct clause (as in My grandmother, I remember when she used to work, we'd get milk and a pound of butter, from Prince, this volume, ex. (6c)). In situations like these, the Hanging Topic construction seems to be the only possibility, but I have no information on its actual usage in spoken Dutch.

15. These and following examples are not actually recorded utterances, but are constructed by the author.

16. Note that as always, the presence of the d-word does not appear to be obligatory. The point is that in all fronting constructions, the d-word is possible. Again, it seems that in the cases discussed here, sentences with a d-word are more felicitous than sentences without a d-word, but no study of actual spoken Dutch has been made to verify this.

17. See Prince, this volume, section 3, for further discussion of the notion "partially ordered set" in this context.

18. It seems that in Dutch another strategy for creating the focus/focus frame that is characteristic of topicalization in Prince's definition, is Focus Scrambling (discussed in section 1.1.2). The balanced intonational pattern of Focus Scrambling appears to trigger the same inference as does topicalization: it sets up a focus frame, with a stressed constituent further down the sentence providing the missing information. If so, topicalization in Dutch is not characterized by fronting but by leftward shift (with the required intonational pattern). I will leave these considerations for further research.

19. Of course the satellite cannot be an arbitrary mediator. It is linked to the d-word, and, by transitivity, to the trace of the d-word, in a number of ways: it agrees with the satellite in $\varphi$-features (cf. (33)), it is interpreted as having the thematic role assigned to the position of the trace of the d-word, etc. Also, sentences with a satellite are always discourselinked. Thus, if there is a satellite, the feature [D] must be present, leading to overt movement of a (possibly empty) d-word in a language like Dutch. If a satellite is not present, the feature may still be present, linking the sentence directly to the discourse instead of to the satellite.

20. Note that the syntax of d-word movement as described here supports Chomsky's (1995) proposal that movement is attraction by a functional head, taking place in order to check the features of the functional head, rather than movement of a phrase, taking place in order to check the features of the phrase. In the absence of a $\mathrm{C}^{\circ}$ head marked [+D], dwords may appear clause internally (i). The absence of a functional head checking the $d-$ word's [D] feature does not lead to nonconvergence:

$\begin{array}{lll}\text { Ik vind } & \text { dat } & \text { vervelend } \\ \text { I find } & \text { that } & \text { irritating }\end{array}$


Possibly, the same is true for wh-movement, where wh-phrases that are not fronted do not lead to nonconvergence. Often, the wh-element receives a different interpretation, as the interrogative interpretation is a function of $\mathrm{C}^{\circ}$ having a $[\mathrm{WH}]$ feature:
(ii) Ik weet wat
I know what
"I know something." 